\title{
Effect of Job Involvement on Employee Performance through Work Engagement at Bank Jatim
}

\author{
Prasetyo ", Amiastuti Kusmaningtyas, Riyadi Nugroho \\ Faculty of Business and Economic, University of 17 August 1945, Surabaya, 60118, Indonesia
}

Received November 18, 2020; Revised January 8, 2021; Accepted February 17, 2021

\section{Cite This Paper in the following Citation Styles}

(a): [1] Prasetyo, Amiastuti Kusmaningtyas, Riyadi Nugroho, "Effect of Job Involvement on Employee Performance through Work Engagement at Bank Jatim," Universal Journal of Management, Vol. 9, No. 2, pp. 29 - 37, 2021. DOI: 10.13189/ujm.2021.090201.

(b): Prasetyo, Amiastuti Kusmaningtyas, Riyadi Nugroho (2021). Effect of Job Involvement on Employee Performance through Work Engagement at Bank Jatim. Universal Journal of Management, 9(2), 29 - 37. DOI: 10.13189/ujm.2021.090201.

Copyright $C 2021$ by authors, all rights reserved. Authors agree that this article remains permanently open access under the terms of the Creative Commons Attribution License 4.0 International License

\begin{abstract}
For companies or organizations to come forward, it is required to have qualified employees. Qualified employees are employees whose performance can meet targets or targets set by the company. High employee performance demands are already part of every company because a successful company cannot be separated from employees who work at the company. In some conditions, employees' performance in a company is inseparable from several factors that can affect it. The purpose of this research is to analyze the influence of job involvement on work engagement; the influence of job involvement on employee performance, and the influence of work engagement on employee performance. This type of research is a descriptive study using a quantitative approach. The population in this study was the Branch Heads and Sub-Branch Managers of Bank Jatim. As many as 191 were taken using saturated sampling techniques The number of samples was used as many as 191 Branch Heads and Sub-Branch Managers of Bank Jatim. The types of data used are quantitative data, and the data source used is the primary data. Collecting data is by distributing questionnaires. Data analysis techniques in this study used partial least square (PLS) analysis. This study proves that Job Involvement has a significant influence on Work Engagement, but Job Involvement has no significant influence on Employee Performance, while Work Engagement has a significant influence on Employee Performance.
\end{abstract}

Keywords Job Involvement, Work Engagement, Employee Performance

\section{Introduction}

For companies or organizations, if they want to move forward, they must have qualified employees. Employee performance demonstrates a person's ability to work. An employee is said to perform well when having the quality of work, which is useful in completing every leader's job. Employees who have good performance can also be seen from their ability to finish their tasks at predetermined time. It can achieve any target stipulated by the company, as stated [1] that employee performance results from quality and quantity achieved by an employee in carrying out his/her duties following the responsibilities given by. The demand for high employee performance is already part of every company because a successful company is not separated from the performance of employees who work at the company. In some performing conditions, employees in a company are not separated from several factors that may affect it.

An intrinsic factor in influencing employee performance is job involvement. Involvement in the work [2] is an attempt to measure the extent to which an individual considers the work essential and the performance achieved as a form of appreciation for him or her. In other words, job involvement is an employee's commitment to his/her work. Employees Involvement is defined by employees' dedication and concern for their work, a feeling that will psychologically get the employee 
to complete the task, and full confidence in his ability to get the job's complete. Furthermore, some researchers revealed that work involvement plays an essential role in determining employees' work performance. Employee engagement has been estimated to impact the organization's actual results [3] significantly. Variable relationships of work engagement and work achievement measured positive relationships from data collected from the banking sector, and the results showed that a da positive relationship between work engagement and work achievement if one thing will both increase, the other automatically increases if the employee is fully engaged and full of motivation will certainly get positive results. His performance will improve from day to day[4]. As such, organizations are incredibly focused on increasing employee engagement to improve their job performance. Work engagement is considered a critical attitude of employees related to work that significantly contributes to increasing active and conscious participation of employees in organizational activities to improve employee work performance and overall organizational performance[5]. The results of the study found that work engagement was positively and significantly related to work performance [5].

Besides, work engagement can also affect performance. Work Engagement is the positivity, fulfillment, and work of the center of the mind characterized [6]. Work Engagement has implications for performance, both individuals and enterprises. This implication is in line with Dajani [7], which proves that employee employment attachment has a significant impact on job performance. Work Engagement is vital in an enterprise because it can positively impact the company's success in achieving its goals. Schiemann [8] points out that attachment has a real positive impact on the number of desired results; employee retention, performance, quality, customer satisfaction, loyalty, and financial performance. The results showed that work engagement has a direct effect on employee performance[9]. Kim et al. [10] also found that work engagement has a significant influence on employee performance.

Based on the existing background description, this study aims: (1) to analyze the influence of Job Involvement on employee Work Engagement at Bank Jatim; (2) to analyze the effect of Job Involvement on Employee Performance on East Java Bank; (3) to analyze the influence of Work Engagement Employee Performance on East Java Bank.

\section{The Foundation of Theory}

\subsection{Job Involvement}

Job Involvement is the level of identifying an employee with his or her work, actively participating in his or her work, and considers his performance in his or her work to be more critical for his good [8]. Job Involvement is a person's level of activity in participating and assessing his work which is important for his self-esteem. [2]. Employees with high levels of Job Involvement firmly recognize correctly and pay attention to the type of work they do. High levels are linked to lower attendance rates and lower employee turnover rates. Whereas according to Rivai and Mulyadi [11], Job involvement is a person's level of liking their job psychologically and attaching importance to their performance for self-esteem.

According to Noe, Hollenbeck, Gerhart \& Wright [12], Job involvement is the level of identification of a person in the work he does. Someone who has high Job Involvement will value his job as important to their life. Doing an excellent job at work will contribute to their self-esteem. For employees who are dissatisfied with low Job Involvement, good or bad performance does not affect one's self-concept.

\subsection{Work Engagement}

Schaufeli and Bakker on [6] said that Work Engagement is the positive energy, compliance, effort of the center of mind that is characterized. Work Engagement is a center of motivational and positive work-related thoughts characterized by passion, dedication and absorption. Robbins and Judge [2] argue that the involvement, satisfaction, and enthusiasm of individual employees to do their jobs are a form of employee engagement. Employees who have a high level of engagement are very impartial and care about the field of work they do. Someone who has a high level of engagement will integrate with his work. Work engagement occurs when an organization member places themselves in a physical, cognitive, and emotional role during work [13].

Work Engagement can estimate employee productivity, organizational success, and financial performance [14]. Schaufeli \& Bakker [6] defines employee engagement as a positive, satisfying state of mind, a viewpoint related to his work. Engagement refers to a state of earnest and consistent feeling and thought that focuses not only on specific objects, events, individuals, or behaviors.

\subsection{Employee Performance}

Performance is what employees do or do not do. General employee performance for most occupations includes quantity elements of results, quality of results, timeliness of results, presence, ability to work together [15]. Performance is something produced by the functions or indicators of a job or something that is the profession of nature at any given time [16].

Performance is the achievement of work or work achieved by human resources both in quality and quantity 
of unity while carrying out its work duties following the responsibilities given to it [1]. Performance is a person's achievement in quality and quantity according to the responsibilities that are carried. Also, some factors like: the level of education, initiative, work experience, and spiritual leadership of employees affect a person's performance. One's work will provide feedback for the person to always actively do his work well and hopefully produce good quality work.

Scullen [17] describes work achievements made up by four components; i) general performance, ii) employee performance, iii) technical performance, and iv) organizational performance. Rubina et al. [17] view work achievement as an outcome of three elements: skills, diligence, and the working environment state. Skills include the knowledge, capability, and competencies of employees; diligence is the level of dedication given by employees to get the job done, and the working environment conditions is the accommodation level of such conditions in facilitating employee performance. The general concern for organizations is the performance of their employees regardless of factors and circumstances. Good achievement by employee brings good to organizational performance, which is an indicator of their triumph [17].

\subsection{Research Model}

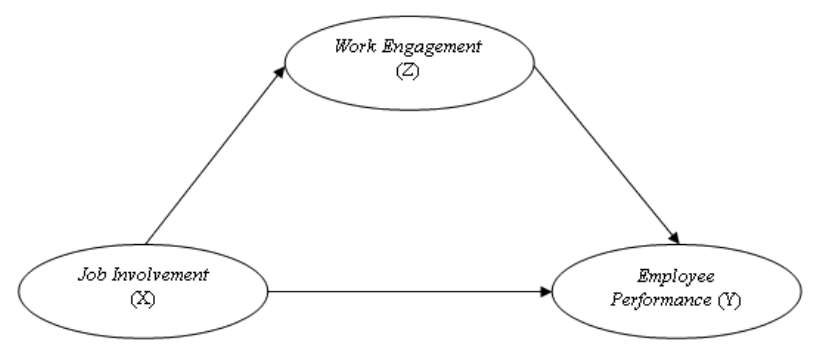

Figure 1. Research Model

Hypothesis

H1: Job Involvement affects employee Work Engagement at Bank Jatim.

H2: Job Involvement affects employee performance at Bank Jatim.

H3: Work Engagement affects employee performance at Bank Jatim

\section{Method}

\subsection{Research Design}

This study used casual research as the type of research. Causal analysis is conclusive research aiming at obtaining evidence related to causal relationships [18]. The smethod used in this research is quantitative. According to [19], quantitative methods are scientific methods whose data are in the form of numbers or numbers that can be processed and analyzed using mathematical or statistical calculations.

\subsection{Population and Sample}

Population points to the whole group of people, events, or things of concern that the researcher wants to probe [20]. The populations used and researched in this study are employees with work areas in Surabaya Branch and East Java Bank Auxiliary Branch with as many as 365 people.

Table 1. Employee Population Data in Surabaya Branch and East Java Bank Auxiliary Branch

\begin{tabular}{|c|c|c|}
\hline No. & Cabang & Jumlah \\
\hline 1 & Bank Jatim Cabang Pembantu Untag & 45 \\
\hline 2 & Bank Jatim Cabang Pembantu Rungkut & 38 \\
\hline 3 & Bank Jatim Cabang Pembantu Tenggilis & 32 \\
\hline 4 & Bank Jatim Cabang Pembantu Rajawali & 22 \\
\hline 5 & Bank Jatim Cabang Pembantu Universitas & 12 \\
\hline 6 & Wijaya Kusuma & 35 \\
\hline 7 & Bank Jatim Cabang Pembantu Juanda & 13 \\
\hline 8 & Bank Jatim Cabang Pembantu Pogot & 26 \\
\hline 9 & Bank Jatim Cabang Pembantu Darmo & 34 \\
\hline 10 & Bank Jatim Cabang Pembantu Tambak Rejo & 15 \\
\hline 11 & Bank Jatim Cabang Pembantu Wiyung & 21 \\
\hline 12 & Bank Jatim Cabang Pembantu Injoko & 23 \\
\hline 13 & Bank Jatim Cabang Pembantu PJTKI & 11 \\
\hline 14 & Bank Jatim Cabang Pembantu PGS & 18 \\
\hline 15 & Bank Jatim Cabang Pembantu Benowo & 20 \\
\hline & Jumlah & 365 \\
\hline
\end{tabular}

Source: Internal Company, 2020

In a quantitative approach, a sample is a group of individuals with some common characteristics identified and studied by researchers[21]. The sample withdrawal techniques in this study used Proportional Sampling. This sampling aims to represent the entire population. The Slovin formula is used to measure the total number of samples [19]:

$$
\mathrm{n}=\frac{N}{1+N e^{2}}
$$

Which:

$\mathrm{N}=\quad$ Population Numbers

$\mathrm{n}=$ Number of Samples

$\mathrm{e}=$ Percent inaccuracy leniency $5 \%$

$\mathrm{n}=\frac{365}{1+\left(365\left(0,05^{2}\right)\right)}$

$\mathrm{n}=190,8$ 
Based on the Slovin formula results above, we obtained a sample of 190.8, which was rounded up to 191 samples from 365 . So the samples used in this study were as many as 191 employees of the Surabaya Branch and East Java Bank Auxiliary Branch. Here is a sample share for each:

Table 2. Research Samples

\begin{tabular}{|c|c|c|c|}
\hline No. & Cabang & Population & Sample \\
\hline 1 & $\begin{array}{c}\text { Bank Jatim Cabang } \\
\text { Pembantu Untag }\end{array}$ & 45 & $\begin{array}{c}(45 / 365) \times \\
191=24 \\
\end{array}$ \\
\hline 2 & $\begin{array}{l}\text { Bank Jatim Cabang } \\
\text { Pembantu Rungkut }\end{array}$ & 38 & $\begin{array}{c}(38 / 365) \times \\
191=20 \\
\end{array}$ \\
\hline 3 & $\begin{array}{l}\text { Bank Jatim Cabang } \\
\text { Pembantu Tenggilis }\end{array}$ & 32 & $\begin{array}{c}(32 / 365) \times \\
191=17\end{array}$ \\
\hline 4 & $\begin{array}{l}\text { Bank Jatim Cabang } \\
\text { Pembantu Rajawali }\end{array}$ & 22 & $\begin{array}{c}(22 / 365) \times \\
191=12 \\
\end{array}$ \\
\hline 5 & $\begin{array}{c}\text { Bank Jatim Cabang } \\
\text { Pembantu Universitas } \\
\text { Wijaya Kusuma }\end{array}$ & 12 & $\begin{array}{l}(12 / 365) \times \\
191=6\end{array}$ \\
\hline 6 & $\begin{array}{c}\text { Bank Jatim Cabang } \\
\text { Pembantu Klampis Jaya }\end{array}$ & 35 & $\begin{array}{c}(35 / 365) \times \\
191=18 \\
\end{array}$ \\
\hline 7 & $\begin{array}{c}\text { Bank Jatim Cabang } \\
\text { Pembantu Juanda }\end{array}$ & 13 & $\begin{array}{c}(13 / 365) \times \\
191=7 \\
\end{array}$ \\
\hline 8 & $\begin{array}{c}\text { Bank Jatim Cabang } \\
\text { Pembantu Pogot }\end{array}$ & 26 & $\begin{array}{c}(26 / 365) x \\
191=14 \\
\end{array}$ \\
\hline 9 & $\begin{array}{c}\text { Bank Jatim Cabang } \\
\text { Pembantu Darmo }\end{array}$ & 34 & $\begin{array}{c}(34 / 365) \times \\
191=18 \\
\end{array}$ \\
\hline 10 & $\begin{array}{c}\text { Bank Jatim Cabang } \\
\text { Pembantu Tambak Rejo }\end{array}$ & 15 & $\begin{array}{c}(15 / 365) \times \\
191=8 \\
\end{array}$ \\
\hline 11 & $\begin{array}{c}\text { Bank Jatim Cabang } \\
\text { Pembantu Wiyung }\end{array}$ & 21 & $\begin{array}{c}(21 / 365) \times \\
191=11 \\
\end{array}$ \\
\hline 12 & $\begin{array}{c}\text { Bank Jatim Cabang } \\
\text { Pembantu Injoko }\end{array}$ & 23 & $\begin{array}{c}(23 / 365) \times \\
191=12 \\
\end{array}$ \\
\hline 13 & $\begin{array}{c}\text { Bank Jatim Cabang } \\
\text { Pembantu PJTKI }\end{array}$ & 11 & $\begin{array}{c}(11 / 365) x \\
191=6\end{array}$ \\
\hline 14 & $\begin{array}{c}\text { Bank Jatim Cabang } \\
\text { Pembantu PGS }\end{array}$ & 18 & $\begin{array}{c}(18 / 365) \times \\
191=9 \\
\end{array}$ \\
\hline 15 & $\begin{array}{c}\text { Bank Jatim Cabang } \\
\text { Pembantu Benowo }\end{array}$ & 20 & $\begin{array}{c}(20 / 365) \times \\
191=10\end{array}$ \\
\hline & Jumlah & 365 & 191 \\
\hline
\end{tabular}

Source: Processed Researchers, 2020

Based on the calculation above, the sample used in this study is as many as 191 employees of Surabaya Branch and East Java Bank Auxiliary Branch.

\subsection{Variable Operational Definitions}

\section{A. Exogenous Variables}

Exogenous variables are often referred to as stimulus variables, predictors, and adherents. Exogenous variables are often also called free variables that influence endogenous variables [22]. The exogenous variable in this study is Job Involvement (X). Job Involvement in this study was measured through several indicators referring to Ansel [23], namely:

a). Actively participate in work

b). Putting work first

c). Important work for self-esteem

\section{B. Intervening Variables}

Intervening variables are known as mediation variables that explain the relationship between independent and dependent variables; he did not change his relationship but explained it. The intervening variable in this study is Work Engagement (Z). Work Engagement in this study was measured through several indicators referring to Schaufeli et al. [24], namely:
a). Vigor
b). Dedication
c). Absorption

\section{Endogenous Variables}

Endogenous variables are variables that change as the implications of changes in exogenous variables [22]. The endogenous variable in this study was Employee Performance (Y). Employee Performance in this study was measured through several indicators referring to Wirawan [16], namely:
a). Work results
b). Work behavior
c). Personal attitude

\subsection{Types and Data Sources}

The data sources used are primary data. According to Sekaran \& Bougie, primary data are how data are collected from sources on the variable of interest for the specific purpose of the study [20]. The primary data in the study were gained through questionnaires that have been filled out by respondents containing statements according to variables that have been designed by providing alternative answers.

\subsection{Data Collection Methods}

This research will use various methods in collecting the data needed to conduct research, namely: library studies, field observations, and data collection through questionnaires. This study used primary method for data collection, which is carried out by disseminating questionnaires. Questionnaires are a series of previously formulated written questions in which respondents record their answers, usually in a more closely defined alternative [19]. Questionnaires are built according to the theories that have been collected and will be measured on the Likert Scale. Likert scale is defined by Cooper et al. [25] as a variation of the summed scale, which consists of statements stating an excellent or unpleasant attitude towards an object of interest or action. The Likert scale is aligned into five options, namely:

1. Strongly Disagree (STS)

2. Disagree (TS)

3. Entirely Agree (CS)

4. Agree (S)

5. Strongly Agree (SS) 


\subsection{Data Analysis Techniques}

The data analysis technique used in this study was Partial Least Square. According to Abdillah \& Jogiyanto [26], PLS (Partial Least Square) is a variant-based structural equation analysis (SEM) that can test measurement models and test structural models simultaneously. Measurement models are used for validity and reliability tests, while structural models are used for causality tests (hypothesis testing with prediction models). Furthermore, Abdillah \& Jogiyanto [26] stated the analysis of Partial Least Squares (PLS) is a multivariate statistical technique that compares between dependent and independent variables. PLS is one of sem's variant-based statistical methods designed to resolve multiple regressions when specific data problems occur. According to Ghozali [27] explained, PLS is a soft modeling analysis technique because it does not presume the data should be with a particular scale measurement, which means even small number of samples can be used (below 100 samples).

\section{Analysis Results}

\subsection{Outer Model}

Outer Model is often also called external relation or measurement model, specifying the connection between the variables studied and the indicators.

\section{Convergent Validity}

To determine the validity of indicators, Measurement model tests through-loading factor done by looking at the validity value of convergent indicators in the Model. Each indicator in the Model must fulfill convergent validity, i.e., has a value of $>0.5$. If each indicator already has a loading factor value $>0.5$, the evaluation step can be continued.

Based on Table 3, all variable measurements are declared valid as the measuring instrument of the constrac, and the indicator item has a convergent validity value $>$ 0.5 .

Table 3. Convergent Validity

\begin{tabular}{|c|c|c|c|c|c|}
\hline & $\begin{array}{c}\text { Original Sample } \\
(\mathrm{O})\end{array}$ & $\begin{array}{c}\text { Sample Mean } \\
(\mathrm{M})\end{array}$ & $\begin{array}{c}\text { Standard } \\
\text { Deviation } \\
(\mathrm{STDEV})\end{array}$ & $\begin{array}{c}\text { T Statistics } \\
(|\mathrm{O} / \mathrm{STDEV}|)\end{array}$ & P Values \\
\hline X.1 <- Job Involvement (X) & 0,678 & 0,674 & 0,046 & 14,845 & 0,000 \\
\hline X.2<- Job Involvement (X) & 0,757 & 0,753 & 0,034 & 22,351 & 0,000 \\
\hline X.3<- Job Involvement (X) & 0,775 & 0,773 & 0,029 & 26,663 & 0,000 \\
\hline X.4<- Job Involvement (X) & 0,759 & 0,756 & 0,043 & 17,506 & 0,000 \\
\hline X.5<- Job Involvement (X) & 0,682 & 0,685 & 0,043 & 16,028 & 0,000 \\
\hline X.6<- Job Involvement (X) & 0,620 & 0,623 & 0,046 & 13,524 & 0,000 \\
\hline Y.1<- Performnce (Y) & 0,767 & 0,761 & 0,031 & 25,117 & 0,000 \\
\hline Y.2<- Performance (Y) & 0,727 & 0,723 & 0,037 & 19,815 & 0,000 \\
\hline Y.3<- Performance (Y) & 0,791 & 0,790 & 0,026 & 30,455 & 0,000 \\
\hline Y.4<- Performance (Y) & 0,756 & 0,756 & 0,027 & 27,802 & 0,000 \\
\hline Y.5<- Performance (Y) & 0,841 & 0,839 & 0,026 & 32,757 & 0,000 \\
\hline Y.6<- Performance (Y) & 0,503 & 0,502 & 0,067 & 7,488 & 0,000 \\
\hline Z.1<- Work Engagement (Z) & 0,790 & 0,788 & 0,027 & 29,535 & 0,000 \\
\hline Z.2<- Work Engagement (Z) & 0,774 & 0,774 & 0,031 & 25,121 & 0,000 \\
\hline Z.3<- Work Engagement (Z) & 0,813 & 0,809 & 0,034 & 24,216 & 0,000 \\
\hline Z.4<- Work Engagement (Z) & 0,702 & 0,701 & 0,042 & 16,525 & 16,763 \\
\hline Z.5<- Work Engagement (Z) & 0,749 & 0,744 & 0,045 & 11,388 & 0,000 \\
\hline Z.6<- Work Engagement (Z) & 0,596 & 0,595 & 0,052 & 0,000 \\
\hline
\end{tabular}




\section{Discriminant Validity}

Table 4. Cross Loading

\begin{tabular}{|c|c|c|c|}
\hline & $\begin{array}{c}\text { Job Involvement } \\
(\mathbf{X})\end{array}$ & $\begin{array}{c}\text { Performance } \\
(\mathbf{Y})\end{array}$ & $\begin{array}{c}\text { Work } \\
\text { Engagement (Z) }\end{array}$ \\
\hline X.1 & 0,678 & 0,429 & 0,490 \\
\hline X.2 & 0,757 & 0,496 & 0,613 \\
\hline X.3 & 0,775 & 0,568 & 0,561 \\
\hline X.4 & 0,759 & 0,530 & 0,539 \\
\hline X.5 & 0,682 & 0,575 & 0,514 \\
\hline X.6 & 0,620 & 0,519 & 0,409 \\
\hline Y.1 & 0,476 & 0,767 & 0,478 \\
\hline Y.2 & 0,530 & 0,727 & 0,455 \\
\hline Y.3 & 0,640 & 0,791 & 0,675 \\
\hline Y.4 & 0,619 & 0,756 & 0,657 \\
\hline Y.5 & 0,538 & 0,841 & 0,560 \\
\hline Y.6 & 0,358 & 0,503 & 0,352 \\
\hline Z.1 & 0,562 & 0,629 & 0,790 \\
\hline Z.2 & 0,528 & 0,572 & 0,774 \\
\hline Z.3 & 0,563 & 0,527 & 0,813 \\
\hline Z.4 & 0,551 & 0,430 & 0,702 \\
\hline Z.5 & 0,511 & 0,478 & 0,749 \\
\hline Z.6 & 0,531 & 0,604 & 0,596 \\
\hline & & & \\
\hline
\end{tabular}

Based on Table 4 which is obtained entirely from the construct, the formers are declared to be good discriminant because all of them have a correlation value of indicators with constructs that is greater than other constructs. Another criterion for obtaining discriminant validity is to look at the correlation value of one contract with another. The reference value of each construct is the square root of the ave value of the construct. The construct has good convergence if the AVE value is $>0.50$

Table 5. AVE

\begin{tabular}{|c|c|}
\hline & AVE \\
\hline Job Involvement $(\mathrm{X})$ & 0,510 \\
\hline Performance $(\mathrm{Y})$ & 0,546 \\
\hline Work Engagement $(\mathrm{Z})$ & 0,549 \\
\hline
\end{tabular}

In Table 5, the ave value $>0.5$ is obtained, and then the indicators in each construal have been converging with the other items in one measurement.

\section{Composite Reliability}

Table 6. Composite Reliability

\begin{tabular}{|c|c|}
\hline & Composite Reliability \\
\hline Job Involvement $(\mathrm{X})$ & 0,861 \\
\hline Performance $(\mathrm{Y})$ & 0,876 \\
\hline Work Engagement $(\mathrm{Z})$ & 0,878 \\
\hline
\end{tabular}

Based on Table 6, all constructs have a composite reliability value above 0.60 which means that all variables have good consistency in measuring the latent constructs measured for use in further analysis.

\subsection{Inner Model}

The inner model in this section will describe the structural model and the influence between the research variables.

\section{Inner Model Test or Structural Model Test}

To measure the level of suitability of the model in the influence of each variable under study, it is measured from the resulting $\mathrm{R} 2$ value, where if $\mathrm{R} 2$ is 0.67 then the model is good, 0.33 then the model is "moderate", 0.19 then the model is "weak" [20]. Pls output as described below:

Table 7. R-Square Score

\begin{tabular}{|c|c|c|}
\hline & R-Square & Q-Square \\
\hline Job Involvement (X) & & \\
\hline Work Engagement (Z) & 0.621 & 0.825 \\
\hline $\begin{array}{c}\text { Employee Performance } \\
(\mathrm{Y})\end{array}$ & 0.539 & \\
\hline
\end{tabular}

The table above shows that the Job Involvement variable affecting Competitive Advantage has an R2 value of 0.621, which means the "moderate" Model. Meanwhile, the Job Involvement and Work Engagement variables that affect Employee Performance have an R2 of 0.539, indicating a "moderate" model. The Q2 value is 0.825 which is in the "strong" category. According to Ghozali [20], Q2 values can be used to measure how well models and parameter estimates generate observational values. So the predicted Q2 value performed by the Model is judged to have predictive relevance. 


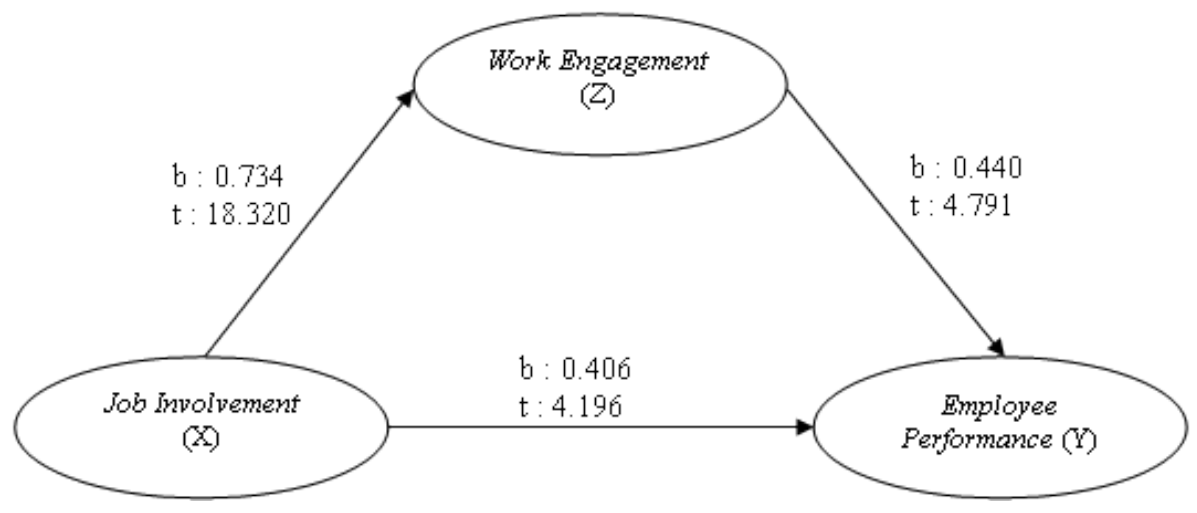

Figure 2. Model Inner PLS

As Figure 2 show as the result of the value of inner weight, Job Involvement affect Work Engagement, while both Job Involvement and Work Engagement affect the Employee Performance by structural equations as follows:

$$
\begin{aligned}
& Z=0.734 X \\
& Y=0.406 X+0.440 Z
\end{aligned}
$$

\section{Hypothesis Testing}

\section{A. Hypothesis Test 1}

The first hypothesis test was known that the statistical $\mathrm{t}$ value was 18,320 or $>1.96$. So it can be interpreted that Job Involvement has a significant effect on Work Engagement in Bank Jatim. The direction of job involvement and work engagement relationships is positive, so the higher the job involvement, the higher the work engagement by having a considerable influence of 0.734 .

\section{B. Hypothesis Test 2}

The second hypothesis test is known that the statistical $t$ value is 4,196 or $>1.96$. So it can be interpreted that Job Involvement has a significant effect on employee performance at Bank Jatim. The direction of job involvement and employee performance is buoyant, so it can be interpreted that the higher the job involvement, the higher the employee's performance by having an enormous influence of 0.406 .

\section{Hypothesis Test 3}

The third hypothesis test is known that the statistical $t$ value is 4,791 or $>1.96$. So it can be interpreted that Work Engagement has a significant effect on employee performance at Bank Jatim. The direction of the work engagement relationship and employee performance is positive so that the higher the work engagement, the more significantly improved the employee performance by having a considerable influence of 0.440 .

\section{Discussion}

A. The Effect of Job Involvement on Work Engagement
The results of data analysis that has been conducted above, found that Job Involvement has a significant positive impact on Work Engagement at Bank Jatim as the T-statistical value of 18,320 , which is far greater than 1.96 so that it can be concluded that high Job Involvement cannot be recognized through the absence of excellent Job Involvement. Thus, the first hypothesis that reads, "Job Involvement affects Work Engagement employees at Bank Jatim," is accepted and proven genuine.

These results show that the higher the Job Involvement, the higher the Work Engagement. In other words, Job Involvement will be able to increase Work Engagement, so if Bank Jatim wants to increase Work Engagement, then it is crucial to pay attention to the extent of Job Involvement owned by Employees of East Java Bank. According to Robbins and Judge [2], it is the level at which a person identifies with a job, actively participates in it, and considers performance necessary for self-worth.

B. The Effect of Job Involvement on Employee Performance

The results of data analysis that has been conducted above, show that Job Involvement has significant positive impact on Employee Performance at Bank Jatim as the T-statistical value of 4,196, which means it is more significant than 1.96 , so it can be interpreted that good Employee Performance can be recognized through the excellent Job Involvement. Thus, the second hypothesis that reads, "Job Involvement affects employees' performance at Bank Jatim," is accepted and proven to be true.

These results show that the higher the Job Involvement, the higher the Employee Performance. In other words, Job Involvement will be able to improve Employee Performance, so if Bank Jatim wants to Improve Employee Performance, then it is vital to pay attention to the extent of Job Involvement owned by Employees of East Java Bank. This is in line with Nasir et al. [4], which states that a da positive relationship between work engagement and work achievement if one thing both will increase, the other automatically increases if the employee is fully engaged and full of motivation will get positive 
results. His performance will improve from time to time. These results also support Thevanes and Dirojan [5], which found a positive and significant relationship between work engagement and work achievement.

\section{The Effect of Work Engagement on Employee Performance}

The data analysis results have proven that Work Engagement has a significant and positive effect on employee performance at Bank Jatim as evidenced by a T-statistical value of 4,791 , which means it is more significant than 1.96 , so it can be explained that high employee performance can be established through the high work engagement. Thus, the eleventh hypothesis that reads, "Work Engagement affects employees' performance at Bank Jatim," is accepted and proven genuine.

This study's results are in line with the findings of research conducted by Dajani [7], which proves that employee employment attachment has a significant impact on job performance. Work Engagement is essential in an enterprise because it can positively impact the company's success in achieving its goals. These results also support Tho'in and Muliasari [9], who found that work engagement directly affects employee performance. This result is also similar with Kim et al. [10], who also found that work engagement significantly influences employee performance.

\section{Conclusions}

Based on the results of the analysis and testing of the hypothesis obtained, it can be concluded that:

1. Job Involvement has a significant and positive effect on Work Engagement at Bank Jatim. These results suggest that the first hypothesis was accepted and proven to be true.

2. Job Involvement has a significant and positive effect on employee performance at Bank Jatim. These results suggest that the second hypothesis is accepted and proven to be true. These results also support several previous findings such as Nasir et al. [4] and Thevanes and Dirojan [5]

3. Work Engagement has a significant and positive effect on employee performance at Bank Jatim. These results suggest that the third hypothesis is accepted and proven to be true. These results also support some previous findings, such as Dajani [7], Tho'in dan Muliasari [9], and Kim et al. [10].

\section{Acknowledgments}

The authors are very grateful to our colleagues for their appropriate and constructive suggestions and support us. We also want to extend our gratitude to the anonymous reviewer for their suggestions to improve this paper.

\section{REFERENCES}

[1] A. P. Mangkunegara, Manajemen Sumber Daya Manusia Perusahaan. Bandung: Remaja Rosdakarya, 2013.

[2] S. P. Robbins and T. A. Judge, Organizational Behavior, Seventeenth. New Jersey: Pearson Education, Inc, 2017.

[3] P. F. Rotenberry and P. J. Moberg, "Assessing the impact of job involvement on performance," Manag. Res. News, vol. 30, no. 3, pp. 203-215, 2007, DOI: $10.1108 / 01409170710733278$.

[4] S. Bin Nasir, R. F. Goraya, U. Arshad, F. Bin Nasir, and A. I. Cheema, "The impact of job involvement, reward system on employees job performance," Elixir Manag. Arts 41, vol. 41, pp. 5963-5968, 2011.

[5] N. Thevanes and T. Dirojan, "Impact of Training and Job Involvement on Job Performance," Int. J. Sci. Manag. Res., vol. 1, no. 1, pp. 1-10, 2018.

[6] W. B. Schaufeli and A. B. Bakker, "Defining and measuring work engagement: Bringing clarity to the concept.," in $A$. B. Bakker (Ed.) \& M. P. Leiter, Work engagement: A handbook of essential theory and research, New York: Psychology Press, 2010, pp. 10-24.

[7] M. A. Z. Dajani, "Relationships between excretion of steroid hormones and tryptophan metabolites in patients with breast cancer. " J. Bus. Manag. Sci., vol. 3, no. 5, pp. 138-147, 2015, DOI: 10.1093/ajen/24.6.694.

[8] W. A. Schiemann, Aligment Capability Engagement. Jakarta: PPM Manajemen, 2011.

[9] M. Tho'in and D. Muliasari, "Peer Reviewed - International Journal International Journal of Economics , Business and Accounting Research ( IJEBAR ) Peer Reviewed International Journal E-ISSN : 2614-1280 P-ISSN 2622-4771," Int. J. Econ. Bus. Account. Res. Peer, vol. 2020, no. 2, pp. 222-228, 2020.

[10] W. Kim, S. J. Han, and J. Park, "Is the role of work engagement essential to employee performance or 'nice to have'?," Sustain., vol. 11, no. 4, pp. 1-16, 2019, doi: $10.3390 /$ su11041050.

[11] V. Rivai and D. Mulyadi, Kepemimpinan dan Perilaku organisasi, 3rd ed. Jakarta: PT. Rajagrafindo Persada, 2012.

[12] R. A. Noe, J. R. Hollenbeck, B. Gerhart, and P. M. Wright, Fundamental of Human Resource Management : Gaining A Competive Advantage. 2016.

[13] F. Luthans and B. J. Avolio, "Brief Summary of Psychological Capital and Introduction to the Special Issue," J. Leadersh. Organ. Stud., vol. 21, no. 2, pp. 125-129, 2014, doi: $10.1177 / 1548051813518073$.

[14] R. Bates and E. F. Holton, "Linking workplace literacy skills and transfer system perceptions," Hum. Resour. Dev. Q., vol. 15, no. 2, pp. 153-170, 2004, doi: 10.1002/hrdq.1096.

[15] R. L. Mathis and J. H. Jackson, Human Resource Management: Personnel Human Resource Management, 
13th ed. Mason: South-Western, Cengage Learning, 2010.

[16] Wirawan, Evaluasi Teori, Model, Standar, Aplikasi, dan Profesi. Depok: PT Raja Grafindo Persada, 2012.

[17] C. Lopes and D. Kachalia, "Impact of Job Stress on Job Satisfaction of Employees Working in Banking Sector," Int. J. Sci. Technol. Manag., vol. 5, no. 3, pp. 103-115, 2016 , [Online]. Available: http://www.ijstm.com/images/short_pd f/1457509824_735H.pdf.

[18] N. K. Malhotra and S. Dash, Marketing Research: An Applied Orientation, Fifth Edit. New Delhi: Dorling Kindersley Pvt. Ltd. Licences of Pearson Education in South Asia, 2009.

[19] U. Sekaran, Research Methods for Business. Jakarta: Salemba Empat, 2013.

[20] U. Sekaran and R. Bougie, Research Methods for Business: A skill Building Approach. New York: John Wiley \& Sons, Inc, 2016.

[21] J. W. Creswell, Research design: qualitative, quantitative, and mixed methods approaches, 4th-ed ed. United Kingdom: Sage Publications, Inc, 2014.
[22] M. Denscombe, The Good Research Guide For Small-Scale Social Research Projects, 5th ed. England: Open University Press, 2014

[23] S. W. Maria Finsensia Ansel, "Pengaruh Keterlibatan Kerja Dan Kepuasan Kerja Terhadap Komitmen Organisasi Polisi Di Kepolisian Resor (Polres) Ende," J. Ilm. Psikol. Gunadarma, vol. 8, no. 1, p. 99186, 2015.

[24] E. Fatmasari, M. Mochammad Al, and A. T. Wulida, "The Effect of Quality of Work-Life and Motivation on Employee Engagement with Job Satisfaction as an Intervening Variable," RJOAS, vol. 2, no. 74, pp. 108-114, 2018, doi: DOI https://doi.org/10.18551/rjoas.2018-02.12 THE.

[25] D. R. Cooper, P. S. Schindler, and J. . Sharma, Business Research Methods, 11th Editi. New Delhi: Tata Mc Graw Hill, 2012.

[26] W. Abdillah and H. Jogiyanto, Partial Least Square (PLS) Alternatif SEM Dalam Penelitian Bisnis. Yogyakarta: Penerbit Andi, 2009.

[27] I. Ghozali, Partial Least Square: Konsep, Teknik dan AplikasiSmartPLS 2.0 M3. Semarang: Badan Penerbit Universitas Diponegoro, 2012. 